\title{
The Changing Media Representation of T. E. Lawrence and Celebrity Culture in Britain, 1919-1935.
}

This article presents a new analysis of representations of T. E. Lawrence to explore how the media created celebrity identities in interwar Britain. ${ }^{1}$ Lawrence's life-story is well known, from his military campaign in the Arabian Desert during the First World War, through his emergence onto the public stage in American journalist Lowell Thomas's touring travelogue, and because of his later attempts to evade the media's limelight. ${ }^{2}$ While several scholars have examined Lawrence's cultural significance, Graham Dawson's important study demonstrated how Thomas's travelogue presented Lawrence as an imperial soldier hero for the 1920s, his complex public image tailored to alleviate social anxieties regarding the instability of British masculinities in this period. ${ }^{3}$ With the growing modernist interest in subjective interiority, Dawson also showed how later biographies presented psychological readings of Lawrence's actions. Most recently, Priya Satia has argued that the press exploited Lawrence's mysterious reputation to peddle rumours about the secret activities of the British state in the Middle East, turning him into the 'poster-boy' for new practices of imperial governance. ${ }^{4}$

Although these studies quote newspapers, no scholar has mapped Lawrence's changing media representation in any detail. The following article examines Lawrence's appearance in seventeen national newspapers and in newsreels between 1919 and 1935, to show how earlier press depictions that largely followed Lowell Thomas's portrayal of an imperial adventurer were transformed by a nascent media-driven celebrity culture that aimed to uncover intimate details of the lives of the famous. ${ }^{5}$ Satia rightly identified how some newspapers presented Lawrence as the 'arch spy of the world' when he returned to England in 1929 after his time in India, but this image of him as an imperial adventurer was already in decline. ${ }^{6}$ By then, the press's attention had switched from Lawrence as a hero of empire to focus on the intensely private man who lay behind the public image of the 'Blonde Bedouin'. ${ }^{7}$ This shift in emphasis revealed a significant change in the way the media constructed celebrity in interwar Britain. In the early 1920s, the public identities of famous people like Lawrence went uncontested by the press, journalists collectively reproducing his image as a mysterious adventurer. However, 
over the course of the 1920s, reporters increasingly challenged the image of the imperial hero as they developed an acute interest in the man behind the persona, newspapers intensifying their exposure of celebrities' private lives to foster emotional connections between the British mass public and famous individuals.

Celebrity culture has received growing attention from scholars in recent years. ${ }^{8}$ In charting how the production of fame has altered over time, historians have utilized concepts devised by cultural theorists such as Graeme Turner, who has argued that celebrities are made when 'media interest in their activities is transferred from reporting on their public role... to investigating the details of their private lives. ${ }^{99}$ Representation of the celebrity's private life enables media audiences to empathize with him or her. ${ }^{10}$ Charles Ponce de Leon's important research identified how a modern American celebrity culture formed between 1890 and 1940 that was geared towards the exposure of the 'real' self which the media claimed lay behind celebrities' public identities. ${ }^{11}$ This focus on the 'real' self corresponded with the emergence of new modes of self-fashioning, with scholars positioning the interwar period as a formative moment in the emergence of modern interiorized subjectivity. Sharon Marcus has recently commented how 'psychoanalytic theory popularized introspection and encouraged individuals to develop elaborate individual mythologies'. ${ }^{12}$ The conceptualization of the 'self within' emerged contemporaneously with the belief that self-actualization was to be achieved through emotional fulfilment in private life, instigating a shift in self-fashioning that was fully realized in Britain's post-war culture of domesticity. ${ }^{13}$ The interwar media thus exposed celebrities' private lives to offer audiences access to what was increasingly deemed to be the 'real' selves of the famous individuals. Laura Beers has used the term 'political celebrity' to describe the interwar Labour MP Ellen Wilkinson, identifying how her popularity was enhanced through newspaper human-interest stories on her private life which amplified the affective affinity between her and Britain's female readership. ${ }^{14}$ Journalists also devised new narrative themes and rhetorical devices to imbue their insights into celebrities' private lives with authenticity. ${ }^{15}$ Matt Houlbrook's recent work has shown how a fixation with authenticity influenced interwar reporters who tried to infuse the life stories of people who 'faked it' like the 'criminal vamp' 
Josephine O'Dare with verisimilitude. ${ }^{16}$ This article's analysis of Lawrence's media image builds on the work of Ponce de Leon and Houlbrook to show how newspapers and newsreels used new linguistic and visual strategies to expose what they projected as his 'real' self. This article argues that the media's special investment in the creation of insights into Lawrence's private life was characteristic of a new British celebrity culture which, in accordance with the popularization of understandings of the interiorized self, prioritized personal revelation ahead of public appearance.

The first two sections of this article chart the rise and fall of Lawrence's press image as an imperial adventurer. The first section shows how, on learning that Lawrence was hiding at an airbase as an aircraftman in 1922, reporters cast him in a similar role to the 'Lawrence of Arabia' figure created by Lowell Thomas. The press's portrayal of him as a secret agent corresponded with a popular conspiracy culture that encircled the British government and was meant to attract readers attuned to sensational stories of public deception. The second section offers a re-evaluation of the 1929 'arch-spy of the world' rumours which Satia identified to argue that, by the end of the decade, the public image of Lawrence as an adventurer had been superseded by investigations into his desire for peaceful anonymity. Extravagant tales of government duplicity were replaced with press reports which discussed Lawrence's personal motivations for avoiding publicity.

Examining the contradictions inherent in Lawrence's media coverage in the late 1920s, the third section of this article reveals how journalists sought to create an image of his 'real' self. It follows Tom Mole's recent work on Lord Byron to examine how Lawrence influenced his celebrity image. ${ }^{17}$ Whilst Byron used his writings to cultivate new forms of intimacy with his readers, Lawrence developed a reputation for self-effacement by embracing anonymity as an aircraftman. ${ }^{18}$ By keeping journalists and photographers at bay, Lawrence helped construct a persona that was distinguished by its remoteness, frustrating the media's attempts to expose his 'real' self. This frustration fed into a new media discourse in which the press contested reluctant celebrities' behaviour, disputing their claims to modesty and complaining that they neglected their public responsibility. At a time of growing anxiety about how public figures 
communicated their social authority to the new audiences of interwar mass media, the press and newsreels sought to expose famous peoples' private lives to create empathetic links with members of the mass public which would strengthen concepts of trust and leadership. Despite Lawrence's unwillingness to court publicity, the media therefore devised techniques to try to produce what were meant to appear as authentic first-hand insights into his 'real' self.

The final section of this article illuminates the shift in Lawrence's media representation from adventurer to reluctant celebrity by offering the first analysis of his visual iconography between the wars. During his lifetime, Lawrence's visual representation in newspapers and newsreels was mysterious, muddled and characterized by distance between media audiences and the celebrity subject. However, following his fatal motorcycle accident in May 1935, new visual images of him emerged which the media used to present readers and viewers with a more intimate, private vision of Lawrence, in an attempt to create a more relatable, human figure with whom the public could empathize.

\section{Aircraftman John Hume Ross}

Lawrence's media image was at its least complex in the years immediately after the First World War. As Dawson has identified, the American journalist Lowell Thomas presented him as an imperial war hero and brought him to the attention of the English-speaking world in his multimedia travelogue, 'With Allenby in Palestine and Lawrence in Arabia', which he delivered to four million people in London, the British provinces and the Empire. ${ }^{19}$ Thomas presented Lawrence as a brave and intellectually brilliant figure who had dedicated himself to the goals of British victory and Arab independence. According to Thomas, Lawrence united the Arabs by becoming one of them, donning the flowing white robes of a Bedouin and, with their support, performed daring acts of gallantry and clandestine attacks against the Ottoman Turks. According to Dawson, Thomas's image of Lawrence revived the courage and integrity of British masculinity that had been destabilized by the industrialized conflict on the Western Front and offered a justification for the sacrifice of the war years. ${ }^{20}$ Thomas also serialized his 
Lawrence story in the Strand Magazine under the title 'The Uncrowned King of Arabia'. Famed for its fictional stories like Sir Arthur Conan-Doyle's Sherlock Holmes mysteries, the Strand articles amplified the fantasy of Lawrence's wartime exploits. In 1920, newspapers noted that the Prime Minister, David Lloyd George, had expressed admiration for Thomas's creation: 'everything that Mr. Lowell Thomas tells us about Colonel Lawrence is true. In my opinion Colonel Lawrence is one of the most remarkable and romantic figures of modern times. ${ }^{21}$ The Times and Observer referred to Thomas as an authoritative source on Lawrence, echoing the journalist's colourful language in their accounts of his 'romantic and victorious campaign', the 'supernatural powers' that he had exercised over the Arabian tribes, and the 'miracles' he had performed on the battlefield. ${ }^{22}$

Such dramatic descriptions in both the elite and popular press forged an image of 'Lawrence of Arabia' which straddled the boundary between reality and fantasy. Lawrence originally believed he could further the geopolitical interests of the Arabs by letting Thomas tell a version of his story, but later felt the American exploited his reputation for commercial gain, ruefully remarking to a friend that 'in the history of the world (cheap edition) I'm a sublimated Aladdin, the thousand and second Knight, a Strand-Magazine strummer. ${ }^{23} \mathrm{He}$ also felt overwhelmed by the media's subsequent misrepresentation of him and, in August 1922, secretly enlisted in the ranks of the RAF under the assumed name John Hume Ross, in an effort to regain his anonymity.

Lawrence's peace was short-lived. On 27 December 1922, the front-page story of the Daily Express announced that he had enlisted as a private in the British Army and was living 'unknown and unrecognised, performing humdrum barrack routine, in a dull garrison town. ${ }^{24}$ The report was inaccurate. Lawrence was actually training as an aircraftman with the photography section at an air base in Farnborough, but this fabrication was typical of the newspaper coverage which surrounded him. For two weeks the Express and Daily Mail had been investigating rumours that he was stationed at a military facility. The Express had published its discoveries without verification because it was vital to scoop the story ahead of the Mail. ${ }^{25}$ Furthermore, as his earlier press coverage had proven, facts counted for little in 
Lawrence's case and so a torrent of misinformation continued to flow from Fleet Street. The Express was joined by a chorus of voices, each speculating why the 'Uncrowned King of Arabia' had gone into hiding as Aircraftman John Hume Ross. ${ }^{26}$ The Daily Sketch was the only paper to directly pose the question otherwise implicit in the press's reaction: 'why has Colonel Lawrence started again in a much more lowly position than he ever occupied before?'27

At a time when military rank was innately bound to social class it seemed unthinkable that Lawrence would voluntarily choose to join the ordinary rank and file alongside men deemed his inferiors. Nor did the fledgling Air Force carry the same cultural cachet as the Royal Navy or Army. Some reporters therefore conjectured that Lawrence's enrollment concealed a secret motive. For example, the Sketch stated 'the official explanation that he desires "peace and quiet" for a forthcoming literary work is deliciously ingenious. ${ }^{28}$ In fact, Lawrence had, indeed, intended to use the solitude of the barracks to complete the first full text of his now famous war memoir, Seven Pillars of Wisdom, but this scrap of truth was lost in rumours like that spread by the News of the World, which proclaimed 'there is something that this indefatigable searcher after knowledge knew the RAF could teach him, or somewhere it was going where he desired to go also.' ${ }^{29}$ Stephen Heathorn has examined the widespread suspicion of a state cover-up which circulated around the death of Lord Kitchener aboard the HMS Hampshire in 1916, and how enterprising self-publicists exploited these suspicions for commercial gain. ${ }^{30}$ In much the same way, a commercial incentive drove speculation about Lawrence's motives for joining the RAF. The press produced this kind of conspiracy theory that targeted the military authorities in order to entice the attention of readers. As Heathorn acknowledges, politicians proved unwilling to speak out to dispel conjecture for fear of inciting even greater media speculation. ${ }^{31}$ Yet, equally, the Air Ministry's refusal to respond to the press's enquiries on Lawrence only served to fuel speculation about his ostensibly mysterious behaviour.

As early as 1922, newspapers thus constructed a popular image of Lawrence which incorporated far more duplicitous characteristics than previously acknowledged by historians. 
The press reported that he was on a secret assignment in Farnborough and proclaimed him a 'master of disguise'. ${ }^{32}$ The Daily Mirror went as far to state that 'he has chosen the horizonblue uniform of a private in the Air Force as the latest of his many disguises... his comrades in the ranks are unaware of his identity. ${ }^{33}$ Lawrence then can be situated alongside the crooks and confidence tricksters who distinguished interwar popular culture. Angus McLaren has argued that shifts in class, gender and racial systems created a society 'preoccupied by dress and role playing, by visual codes and clues', whilst Houlbrook has revealed the spectacular social mobility afforded conmen who successfully used disguise to masquerade as someone they were not. ${ }^{34}$

Visual images conjured further uncertainty over Lawrence's identity. The most striking photograph to arise from the Ross episode was published on the front-page of the Daily Sketch on 30 December 1922 (Fig.1). Titled 'Colonel as Ranker', the column consisted of three distinct images: a candid photograph of Lawrence in his uniform that had been taken at a distance was juxtaposed above an image of him in Bedouin robes on which was imposed a smaller headshot from his time in the army. The indistinct nature of the long-distance shot and his indistinguishable facial features stimulated speculation over his identity, while the juxtaposition of the three different images reinforced his reputation as a master of disguise.

Overlapping this narrative of masquerade was another discourse that linked Lawrence's purported aptitude for disguise to duplicitous themes and characters from mainstream literary fiction. The secret agent became a popular hero in fiction in these years. ${ }^{35}$ On first 'outing' Ross, the Express likened him to the characters of 'John Buchan's romances' and Kipling's 'Strickland', an undercover policeman renowned for unraveling mysteries in India. ${ }^{36}$ One report linked Lawrence to Conan-Doyle's fictional detective Sherlock Holmes, who had also recently acquired a reputation as a master of international espionage. The 1917 story 'His Last Bow', first published in the Strand Magazine, pitted the sleuth on the side of the British government against a German spy. The Express's exposé claimed that Lawrence had secured special dispensation from the Air Ministry to secretly visit a house with a mysterious 'Green Door' in central London, calling to mind Holmes' base at 221b Baker Street. The newspaper 
enhanced this narrative by claiming that Lawrence received correspondence at the house but that its dwellers 'seldom see him, and know nothing of his movements'. ${ }^{37}$

\section{'The Arch-Spy of the World': The collapse of the secret agent narrative}

In 1922, the media had invested Lawrence's mundane activities with shadowy consequences, recalling fantasies from popular literary fiction. In 1929, the Daily News even labelled Lawrence an 'Eastern Sherlock Holmes', this comparison relating not only to both men's purported talent for disguising themselves and taste for adventure, but also to the way their public images occupied a grey area that blurred fact and fiction. ${ }^{38}$ Importantly though, the presentation of Lawrence as a secret agent had already started to diminish by 1929 . Following his original exposure in 1922, Lawrence was expelled from the RAF. Having spent a brief spell in the Tank Corps, only to again be exposed by the Daily Express in 1924, he was permitted to re-enter the Air Force at the end of 1926 under a new name, Aircraftman T. E. Shaw, which he adopted by deed poll. He requested a post far from the prying eyes of British journalists, and was stationed as an air mechanic at an RAF depot on the North-West Frontier of India. In search of a story, the British press renewed their interest in him at the start of 1928. By the end of the year, their stories had become wholly contrived. The Evening News claimed that Lawrence was on a 'secret mission' in Amritsar disguised as a Mohammedan Saint, using his 'mystical powers' to 'ward off the Evil Eye' whilst undermining Bolshevist activities. ${ }^{39}$ The most outlandish report came from the notoriously sensationalist Empire News which created a nineteenth-century 'Great Game' narrative when it asserted that Lawrence was embroiled in a 'secret duel to the death' with the spy and international confidence man, Trebitsch Lincoln, in order to prevent a war breaking out between Britain and Russia. ${ }^{40}$

Satia has argued that these reports presented the most overtly imperialist rendering of Lawrence from the interwar years. ${ }^{41}$ While this was certainly the case, this persona was not representative of his broader media image. By the later 1920s, the press's interest had started to shift away from the earlier Lawrence fantasy that was reproduced in different guises to 
entertain readers, towards a searching line of enquiry into the 'real' man behind the public persona. This change in approach was partly because speculation had exhausted itself, the most lurid news titles like Empire News distorting his reputation beyond faithful recognition. This exhaustion was demonstrated at the beginning of 1929 when a number of newspapers reported that the Afghanistan authorities had branded Lawrence 'the arch-spy of the world', but were then forced to retract the story when it emerged the rumours were false. ${ }^{42}$ For the first time, Lawrence's media image thus became a point of contention: the arch-spy story was so contrived that the elite press derided it as 'preposterous' and 'utterly unfounded', while the usually uninhibited Express and Mirror refrained from publishing the report at all. ${ }^{43}$ This silence on the part of some of Britain's leading popular newspapers and the forced retraction signalled the limitations to which Lawrence's malleable image as a mysterious adventurer could be exploited for commercial gain when the absurd stories peddled by newspapers like the Empire News had real geopolitical consequences.

The arch-spy debacle led to Lawrence's recall by the British government which wanted to put an end to rumours that had gained currency in the Continental press. The Air Ministry requested that he disembark early from the passenger liner that brought him home, so that he avoided newsmen on arriving in England. However, a barrage of reporters lay in wait for him, one journalist noting that his clandestine arrival had 'not [been] calculated to allay suspicions that [had] gained ground abroad. ${ }^{44}$ The anti-imperial Daily News pushed this agenda further than any other newspaper, using the event as a weapon with which to attack the government. ${ }^{45}$ It recorded how, when journalists accosted Lawrence at Paddington station and asked him his name, he replied that he was called 'Smith'. Rather than interpret this comment for what it was - a ploy used by Lawrence to evade his pursuers - the Daily News presented the 'Smith' remark as proof that he had assumed a new identity aside of his original one and Shaw, declaring the event a 'Treble Identity Drama'. It launched a stinging attack on the authorities for the way they had covered-up his return, demanding that the 'Truth Must Be Told'.

As Satia has discussed, reports like this one used Lawrence's image as an enigmatic fantasy figure to mobilize the belief that Britain maintained an all-seeing secret intelligence 
service in the Middle East. ${ }^{46}$ However, other newspapers ridiculed what they rightly regarded as overblown rumours, showing how Lawrence's persona as a mysterious adventurer was collapsing under its own weight. The Daily Express published an article titled 'The Comedy of Colonel Lawrence' which recorded how M.P.'s had 'laughed at the absurd idea' proposed by a communist politician that Lawrence was still in India and that another man had returned to England in his place. ${ }^{47}$ An editorial in the disapproving Daily News even acknowledged the farcical nature of the sensationalist conjecture it had helped conjure:

Such rumours have been circulated about Col. Lawrence that tribesmen and potentates must sleep more easily in the knowledge that he is home... Perhaps we will have to keep Col. Lawrence in London, and send daily photographs to the East showing "Col. Lawrence going to a garden party," "Col. Lawrence at the hunt," and "Aircraftman Shaw mending a motor-car." Then they will very likely think that he has some dark motive in going about like an Englishman. Such is fame! ${ }^{48}$

This editorial noted how Lawrence's public image had become ensnared in speculation and stated that his fame was to blame for the suspicion, his reluctance to reveal his whereabouts sustaining his reputation as a mystery man. This article was characteristic of a number of newspaper reports from the later 1920s that recognized how Lawrence's refusal to dispel the rumours that surrounded him had served to further stimulate media curiosity in him. These reports tacitly implied that there existed a 'real' man behind the public identity of the adventurer cum secret agent, and were symptomatic of a new celebrity culture which stressed the importance of exposing the private lives of famous individuals. Whereas journalists had previously used Lawrence's past reputation to cultivate an imaginative news genre designed to entertain readers with tales of intrigue and deception, they now turned their focus towards the man behind this persona to uncover his personal reasons for evading their exposure.

\section{'How to be Private': The contradictions of Britain's interwar celebrity culture}

Lawrence's media image illuminates how British celebrity culture changed between the wars in response to social anxieties concerning how a new mass public related to famous people. In his study on American celebrity, Ponce de Leon showed how, by the 1930s, a didactic interest in the lives of the famous had been substituted by a focus on celebrities as psychologically 
complex individuals. Although journalists had written about the home lives of celebrities in the nineteenth century, the increasing significance ascribed to private life as the domain in which modern forms of emotional selfhood could be enacted meant that the media sought to expose the 'real' selves of celebrities through human-interest stories on their personal lives. ${ }^{49}$ British newspapers followed this trend, but engaged in private revelation with a more acute paternalistic agenda. Whereas U.S. celebrity culture was distinguished by a demotic approach to famous individuals, the British media exposed the private lives of celebrities to generate empathy for them among a mass public who, it deemed, required models of selfhood which they could identify with and admire. ${ }^{50}$ Interwar social elites worried that mass culture exerted a powerful hold over public opinion and that it had destabilized the old hierarchy. ${ }^{51}$ A similar anxiety influenced Britain's celebrity culture, the media developing new rhetorical and visual strategies to create a deferential bond of intimacy between audiences and public figures based on trust and authenticity. Lawrence stubbornly defied this celebrity culture through his efforts to avoid reporters and photographers. His later media coverage shows how journalists used new discursive techniques to try and make his 'real' self accessible to audiences but how his inclination for self-effacement undermined their efforts. The result was a media discourse that presented him as a reluctant celebrity and which questioned his modesty. Yet, this vision of Lawrence reveals the crucial meaning attributed to personal insights in fostering the affective, reverential connection between members of the public and popular celebrities.

Following his return to England from India in 1929, newspapers noted how Lawrence's cultivation of remoteness subverted the expectations that the media placed on celebrities in interwar Britain. A Daily Mirror editorial titled 'How to be Private' downplayed how the press's pursuit of him generated heightened interest in him and instead claimed that it was his responsibility to expose himself to the limelight in order to rid himself of media attention:

Evidently it is taking [Lawrence] long - too long - to realise that there's no surer way of becoming immensely famous than to keep intensely quiet. Advertising has done that. Almost everybody advertises. Everybody who wants to be celebrated blows his own trumpet. Consequently the only trumpets that are heard are those that are not sounded. Hence Colonel Lawrence's fame. He must come out, dressed as an Arab... and sound a fanfare. Nobody will notice. He will at once sink into obscurity. ${ }^{52}$ 
The Mirror journalist stated that Lawrence's refusal to publicize had intensified the press's pursuit of him; only by exposing himself and 'sound[ing] a fanfare' would he dispel curiosity.

This editorial indicated how self-exposure had become a vital process in the creation of celebrity identities. Other famous people from this period had more readily responded to this development; the actor Rudolph Valentino attempted to deflect unwanted media attention by writing an article in the Daily Express on his 'double self' in 1925. He lamented that, because of his fame, 'there is no more peace, nor the intimacy of the interior life. ${ }^{53} \mathrm{He}$ regarded the 'screen conception' of him as his 'shadow self', differentiating between this ostensibly false persona and a 'real' Valentino, which he labelled his 'interior self'. He then described how he found an inner fulfillment in his domestic life as an 'ordinary, intelligent, healthy, cultivated man', who enjoyed pastimes like sport, art, literature and dancing. Mirroring the development identified by Ponce de Leon in America, Valentino therefore discursively created an image of a 'real' self that coalesced around expression in private life. The authenticity of his disclosure was enhanced by the confessional tone of his first-person description of his psychological and domestic worlds. The contemplative manner of Valentino's portrayal also conveyed a sense of deep-rooted emotional exploration, revealing how self-actualization was increasingly fused with affective fulfilment in private life in this period. ${ }^{54}$

This kind of human-interest story reproduced an image of the celebrity 'real' self that hinged on private life. Although the 'domestic sketch' had a long pedigree dating back to at least the mid-nineteenth century, it was after the First World War that coverage of a famous person's home life was prioritized by the media. ${ }^{55}$ Indeed, this revelation of the domestic self became a publicity strategy adopted by many famous people to manage their celebrity images in these years. The famous Hollywood couple Mary Pickford and Douglas Fairbanks declared that it was only at home that they behaved ordinarily, thus equating media access to their domesticity with access to their 'real' selves. ${ }^{56}$ In the 1920 s, new genres of British newsreels titled 'The Stars at Home' and 'The Stars as They Are' enabled famous people to promote versions of their 'real' selves through exposure of their home lives. These newsreels included 
scenes of celebrities engaged in everyday activities like gardening, sport and caring for pets. ${ }^{57}$ There was even an attempt to present Lawrence in this way. Following the Express's 1922 exposure of him as John Hume Ross, a lone voice in the press presented British readers with an intimate portrayal of his domestic life. Ignoring the duplicitous narrative publicized by all other newspapers, the Daily News presented Lawrence as 'very modest' and happily at home among the aircraftmen in the barracks at Farnborough:

He is one of twelve in his dormitory. He rises soon after 6 a.m. and does physical training, after which, at 8 o'clock, comes breakfast of ordinary army fare. He parades at 8.45 and goes to the school at 9 o'clock... He goes for walks with his barrack-room chums, plays hockey, joins in a singsong, and is a frequenter of a little teashop, popular with the men near the barracks. ${ }^{58}$

To instill authenticity in this portrayal of Lawrence's domesticity, the journalist stated that he had conversed with the war hero, gleaning these pieces of information first-hand. Although it is unlikely that this conversation occurred, the matter-of-fact tone that characterizes the article enhanced the ostensible verisimilitude of the account and its behind-the-scenes glimpses into Lawrence's private, domestic setting.

In 1922 the Daily News's description of Lawrence's humble existence was exceptional and was drowned out by the false stories peddled by the rest of Fleet Street, which presented him as though he was on a secret mission. This predilection for intrigue may also have been fuelled by the way Lawrence's unusual domestic situation did not create a vision of home life with which media audiences could identify. The News's depiction of the quotidian existence enjoyed by Lawrence, which revolved around a routine of work, sleep, food, friends and fun, was meant to correlate with a new celebrity culture which sought to foster empathetic bonds between the experiences of ordinary people and those of celebrities. Yet, the all-male setting of the barracks vividly contrasted with the comfortable sketches of home life contained in other popular media portrayals like the 'The Stars at Home' films. Furthermore, in a period that saw celebrities like Pickford, Fairbanks and Valentino become defined by their romantic heterosexual personas, Lawrence's nonexistent love-interest also distanced him from popular celebrity culture. ${ }^{59}$ Although the impulse is understandable, scholars have proved overeager to link Lawrence to the title character from E. M. Hull's romantic novel The Sheik (1919), the 
film version of which included Valentino in the lead role and first brought him fame as a Hollywood heartthrob. Lowell Thomas's 'Lawrence of Arabia' and Hull's Sheik were both Englishmen who masqueraded in Bedouin robes and headdress; but, whereas the Sheik was a sexual icon, Lawrence was not presented as a desirable figure. The Daily Express did, in the late 1920s, suggest that either Valentino or Lawrence might have been the 'new type of ladies man'. However, this is the sole article out of the seven hundred reports sampled for this study across almost two decades which linked the men and presented Lawrence as an object of female desire like Valentino. ${ }^{60}$ Equally, only one other article compared Lawrence to a sheik, which suggests that his persona did not incorporate the characteristics of the figure portrayed on screen by Valentino. ${ }^{61}$

In light of the fact Lawrence's sexuality has commanded so much scholarly attention, it is significant that it received so little media coverage in his lifetime. ${ }^{62}$ As John Mack recorded in his study of Lawrence's psychology, the incident that caused most speculation over both his possible homosexuality and 'flogging disorder' was his alleged capture, beating and rape at Deraa by Ottoman Turks in 1916. Yet, as Mack noted, Lawrence's description of this event was only contained in the five private 1922 manuscripts of Seven Pillars of Wisdom housed at the Bodleian library. All mention of the Deraa episode was omitted from the 120 subscribers' editions of Seven Pillars which were published in 1926 and the abridged version, Revolt in the Desert (1927), which was released for public sale the year after. ${ }^{63}$ Only after Lawrence's death in 1935 was the 1926 edition of Seven Pillars reproduced in public form and included, for the first time, its candid portrayal of the homosexual practices of young Arab men. ${ }^{64}$ The limited distribution of Seven Pillars before Lawrence's death restricted speculation about his sexuality. The Daily Mirror explained how the memoir's sexual content had prevented it from being made available to a wider readership, stating how the 1926 edition was sold at very high prices 'due partly to its typographical magnificence; partly to the frankness with which, in this uncensored recital, the author describes the immorals of the wandering Semite. ${ }^{95}$ Although rumours like this one on the sexual themes contained in Seven Pillars might have circulated before Lawrence's death, it is significant that this was the only allusion to its sexual 
content located during the research conducted for this article. As Max Jones recently observed in relation to General Gordon's public image in this period, informal social codes and formal censorship restricted public discussion of transgressive forms of sexuality between the wars. ${ }^{66}$ Inhibited by social etiquette, the small group of readers who had read the unexpurgated text of Seven Pillars thus refrained from publicly commenting on the sexual themes it contained. ${ }^{67}$

Rather than pruriently enquiring into Lawrence's sex life, reporters were preoccupied with assessing his talent for self-effacement. Leo Braudy identified how the 'shy star' was a phenomenon which dated back to at least Jean-Jacques Rousseau, who, despite desiring to be 'spiritually public', tried to be 'physically private'. ${ }^{68}$ The tension evoked by this contradictory attitude similarly characterized Lawrence's public reputation in the late 1920s. His refusal to dispel the gossip that surrounded his alleged exploits as a secret agent led to some cynicism among journalists that he deliberately courted their attention by shying from their advances. The travel writer Rosita Forbes claimed that his modesty was just a 'stunt' and that he was the 'world's premier publicist'. ${ }^{69}$ Yet, this strand of opinion was equally revealing of the media's desire to downplay its role in the creation of popular celebrities. Lawrence refused to openly publicize an image of his 'real' self and this undermined the media's attempts to create an imagined relationship between members of the public and him that appeared natural and unforced; the authenticity of the 'real' self relied on it seeming spontaneous and unprompted. Lawrence's reluctance to self-expose drew unwelcome attention to the cultural mechanisms engaged in creating popular celebrities and challenged the media's role as the conduit through which a mass public could connect to famous individuals.

The editor of the Sunday Express, James Douglas, sympathized with Lawrence. Writing for the Daily Express in 1928 about Pickford and Fairbanks, Douglas had acknowledged both the agency of celebrities and the media in the creation of the formers' fame:

There is no doubt that mass celebrity is a bore and a burden. The children of the limelight long now and then to taste the simple delight of obscurity. The photocracy dread the embraces of democracy. They hate the many-headed monster which they have created and which has created them. ${ }^{70}$ 
While clearly stating that the actor and actress had participated in the creation of their 'mass celebrity', Douglas recognized the key role of the media, which he labelled 'the many-headed monster', in promoting the bond between the famed 'photocracy' and the British public. He then proceeded to discuss Lawrence's reputation, stating that the 'fear of fame is a paradox, for it often makes virtuous modesty more notorious than vicious immodesty.' He claimed that Lawrence and the famously shy novelist J. M. Barrie had 'perfected the art of finding fame by flying from it'. Articles like this one thus noted Lawrence's agency in the creation of his fame through his self-effacement and contributed to a new media narrative that interchangeably ascribed culpability to the reluctant celebrity whose modesty, it was deemed, drew the press's attention, as well as to reporters and photographers who thrived on the mystery and the chase. Significantly, this British discourse was emerging at the same time as similar press coverage encircled the aviator Charles Lindbergh in America. Daniel Boorstin recorded how, when Lindbergh refused to be interviewed, newspapermen 'made columns of copy from [his] efforts to keep out of the news... [some] cynically suggest[ing] that [his] attempts to dodge reporters were motivated by a devious plan to increase his news-interest. ${ }^{, 71}$

In an article that exemplified the new focuses on private life and emotional interiority that dominated celebrity media coverage in the late 1920s, James Douglas again remarked on Lawrence's modesty in his positive portrayal of his 'simple life', the week after he returned to England in 1929. ${ }^{72} \mathrm{He}$ asserted that Lawrence's 'extraordinary form of ascetic hermitage' was the remedy to the 'mental and physical handicaps' which characterized the 'complexity of our civilisation'. He stated that Lawrence had 'once told [him] that he needed only three pounds a week to enable him to live the life of a contemplative scholar. He cares nothing for food and clothes... he does not smoke. He drinks no wine or spirits or beer. I could hardly persuade him to drink a glass of ginger ale!' As with the revelations that the Daily News journalist had presented into Aircraftman Ross's daily routine in 1922, Douglas's depiction of Lawrence's mundane activities joined with the first-hand conversation he purported to have had with him to instill in this account authentic images of Lawrence's 'real' self. Naturally, he substantiated Lawrence's modest reputation, having supposedly gained the access to the reluctant celebrity 
that was denied other reporters, presenting him as an abstemious yet ordinary man: 'In the Air Force he has achieved the final simplification of his life. This is the secret of the mystery which envelops him. He is himself.' Douglas's analysis thus clearly diverged from the kind of sensationalist rumour peddled by the Empire News in this period and demonstrated how the media had started to turn away from the image of the mysterious adventurer to focus more intently on the man within.

Douglas respected Lawrence and tried to present him in an intimate and admiring light in an effort to foster empathy for him among Express readers. However, it seems likely that the descriptions of Lawrence's austere circumstances and his unassuming 'real' self were as tantalizing as they were reassuring in their creation of a persona with which media audiences could identify. Indeed, later on in 1929, the novelist and columnist May Edgington stated that she found Lawrence equally fascinating and repellent: 'what kind of man is this wonder? I do not know and do not want to know; and yet - he interests me. ${ }^{73}$ The most revered celebrities of this period were those who provided the media with what seemed to be unfettered access to their private lives. For example, the famous air pioneers Amy Johnson and Jim Mollison courted the press to publicize their world-record attempts and, after their marriage, allowed journalists to write articles on their domesticity to promote their professional careers. ${ }^{74}$ Nor is it any coincidence that the 1920s and early 1930s witnessed royal celebrities become more popular than ever before. ${ }^{75}$ The British monarchy engaged the emotions of its subjects in a series of media-orchestrated royal weddings which presented the lead protagonists as a normal family, the exposure of their domesticity allowing members of the public to empathize with their activities on an unprecedented level. ${ }^{76}$

It was against this social milieu that a 1933 Daily Mirror report criticized how a small number of what it termed 'coy celebrities', including Lawrence, prevented members of the public from identifying with them. ${ }^{77}$ The report began by ridiculing the recent behaviour of the film actress Greta Garbo who, as Ponce de Leon has noted, was a renowned recluse. ${ }^{78}$ It questioned whether she had the right to be annoyed at fans that had gathered outside her home and pondered the consequences of her fame: 
Publicity! What does it mean in the case of a star like Greta Garbo? It means that the ambitions and ideals of countless thousands of people culminate in her illustrious personality, that she represents for them the realisation of an impossible dream... Her face, her gestures, her dresses, the dramatic roles she plays - are they not a real-life fairy tale, a fulfilment of the wishes of womankind the world over?

The journalist suggested that by shunning publicity, Garbo denied her fans the opportunity to build imagined emotional relationships with her, depriving them of their 'impossible dream'. Despite the implication in this report's title that 'coy celebrities' were only affectedly shy, the article conveyed a genuine concern that, in their reluctance to court publicity, they failed to adhere to the expectations of their admirers. Written at the end of 1933, the Mirror's criticism with its tacit call for redress may have been informed by a more profound anxiety regarding the success with which the European dictators had used new media to create popular celebrity personas to garner the affection of their respective peoples. ${ }^{79}$ The journalist's complaint was symptomatic of the belief that popular celebrities were pillars around which mass society was forming, and that they had a duty to set an example in social responsibility through both their private and public actions. The reporter admonished Lawrence and proclaimed that he had 'an obligation to his fans': 'anyone can be a modest nobody but it takes a real hero to stand up to fame.' He and Garbo were then likened to Lindbergh who, as already mentioned, was equally averse to publicity:

They fill us with the stuff o' dreams, kindle our hero-worship, and then grumble because we want to shout them up to the skies and grip their hand. They make themselves kings and queens of hearts, and then behave like the deuce.

This article objected to the behaviour of those reluctant public individuals who were 'so eager to dodge what the rest of us would give a great deal to experience'. In this respect, they were judged to have failed to live up to their roles as exemplars of a particularly modern selfhood with which members of the public could identify. David Giles has stated that celebrities are symbols of uniquely individualistic forms of selfhood and that fame is intricately bound to a public desire to emulate these highly personalized identities ${ }^{80}$ The Mirror report indicates that it was in the interwar years that this culture of empathetic association crystallized, given how it criticized reluctant celebrities for the way they frustrated this development.

The final twist in the British media's construction of Lawrence's celebrity image came 
in 1934 when the News Chronicle published a front-page story that presented what it termed a 'sketch' of him. It's main headline announced 'Lawrence of Arabia Talks (Exclusive), ${ }^{81}$ The exclusive interview was one of the press's narrative strategies which grew in use between the wars. A search of online newspaper databases shows how the Daily Mirror and Daily Express increasingly used the term 'exclusive' as an advertising ploy to present interviews of famous individuals like members of foreign royal families and notable political leaders like Benito Mussolini and Adolf Hitler. ${ }^{82}$ These articles packaged revelation as authentic insights into the subject's innermost thoughts, often conveying their impassioned opinions. Similarly, Matt Houlbrook has shown how exclusive confessional stories of confidence tricksters became lucrative commodities in the 1920 s, trading on disclosures relating to both an illicit criminal underworld and, more significantly, their emotional interiorities. ${ }^{83}$ The 1934 Lawrence exposé was also couched as his 'confession' in order to create a 'real' self by depicting his ostensible emotional vulnerability, exemplified in the report's first sub-headline which described his 'Bitter Cry: I want to be Left Alone'.

The News Chronicle correspondent J. M. Pughe had intercepted Lawrence at Hythe near Southampton where he was testing speedboats on behalf of the Air Ministry. According to Air Ministry files, Lawrence had refused Pughe an interview, conversing with him in the belief that nothing he said would be reproduced. ${ }^{84}$ However, while Lawrence told his RAF superiors that he had deliberately avoided being interviewed, it seems that he actually took this opportunity to promote an image of himself as a self-effacing ascetic recluse to match the remote persona that he had already helped fashion. Pughe deployed both new and established rhetorical devices to instill authenticity in his report. He recorded how 'in 50 minutes' Lawrence had told him of his 'bitter disillusionment and his resolve that Lawrence of Arabia is dead and that his memory shall, so far as he is able, never be resurrected.' The precise reference to the length of time that the journalist had spent conversing with Lawrence imbued his description with a sense of certainty and fact. He explained how he had infiltrated Lawrence's domesticity, the aircraftman talking to him whilst 'sat on his bed' in his 'modest lodgings'. Pughe also inscribed an emotional intimacy onto Lawrence's outward gestures, his 
body purportedly conveying his inner affective state: 'his eyes have a strange sadness that lingers behind the cynical smile that is so often on his lips'. Before this exclusive, most news reporters had not got close enough to Lawrence to offer their opinion on how his appearance reflected his interiorized emotional condition. Thus, mirroring the period's dual obsessions with celebrities' visual images and the growing influence of psychoanalytic conceptions of the self within, Pughe's words presented readers with a glimpse of a 'real' Lawrence beneath his exterior. Finally, verisimilitude was communicated through the two-thirds of the article in which Lawrence 'spoke', Pughe extensively quoting his opinions on his false reputation as a secret agent, his approaching retirement from the RAF, international developments in Arabia, and his purported aversion to publicity:

"I like my work on aeroplanes, power boats, machines. It is an ordinary man's job. It gives me pleasure. There is no mystery about me. I am just an ordinary man trying to earn his living in the way that he likes. The mystery is fictitious. I want to be left alone, not hounded from pillar to post, not forced to leave my lodgings because I am supposed to be a notorious character. I want to be left alone."

In describing at length how Lawrence sought to avoid the media's limelight, Pughe repeatedly invoked the abiding tension that had characterized his media representation, his identity as a remote figure in conflict with the onus that was placed on interwar celebrities to self-expose. Lawrence's self-revelation in 1934 provided British readers with what seemed to be a more vulnerable and emotionally 'real' image of him by ironically emphasizing his alleged disdain for publicity and his desire to be 'left alone' as an 'ordinary man'.

\section{'Surroundings of the Most Delightful Informality': Lawrence's unstable visual image}

Almost exactly a year after the Chronicle's sketch, on 19 May 1935, Lawrence succumbed to the fatal head injuries he had sustained in a motorcycle accident near his home at Clouds Hill in Dorset. Some newspapers seized on this episode as a commercial opportunity, transforming him back into the mysterious adventure figure of the earlier 1920s. Rumours and speculation once again abounded that he was an intelligence agent, that he was harbouring government secrets, and that there may have been some dark state cover-up behind his untimely demise. ${ }^{85}$ 
Yet, there was also a concerted effort to reveal Lawrence's more personal side in accordance with the demands of a celebrity media genre which thrived on the details of private life. Thus, the popular press stressed the involvement of Lawrence's family in the story. The day after the accident, the Daily Mirror's sub-headline noted how 'relatives race[d] to his bedside' ${ }^{86}$ The Daily Herald drew similar attention to the way Lawrence's 'Brother [had] Arrive[d]' at the hospital while the News Chronicle acknowledged that his 'Mother [was] Unaware' that he had died because she had been living in China. ${ }^{87}$

Some of the visual images that newspapers and newsreels used to portray Lawrence in the wake of his death also revealed how his public reputation had shifted from the imperial adventurer to focus on the 'real' man who lay behind the remote persona. In his lifetime, the press only routinely deployed seven photographs of Lawrence. Most of these were headshots of him dressed in Bedouin robes or military uniform, with just one showing him in civilian clothes. ${ }^{88}$ The press's method of juxtaposing photographs of him in different guises, as shown in the Daily Sketch's positioning of its 1922 Ross image (Fig.1), was a technique regularly used to perpetuate his public image as a duplicitous figure in the early 1920s and immediately after his death. ${ }^{89}$ Significantly, the only image located as part of this investigation which showed Lawrence in civilian dress in his lifetime was used by the Daily Express in the early $1920 \mathrm{~s} .{ }^{90}$ Indeed, this picture was presented on the newspaper's frontpage the day after its Ross exposé in 1922. However, it seems to have been subsequently overlooked by the press in favour of pictures of him in military uniform or Bedouin robes that were more in keeping with his persona as a secret agent. The image of a normal-looking Lawrence with whom the public could more easily identify did not reappear until a week after his death when the Illustrated London News published a full-page studio photograph of his face taken by Howard Coster (Fig.2). ${ }^{91}$ The headline followed Lowell Thomas's description when it proclaimed him 'the most romantic figure of the war', but this close-up photograph of an ordinary-looking, ruddy-faced man presented readers with a more intimate image of Lawrence than ever before.

Advances in photographic technologies should have allowed the media to bring images of Lawrence closer to members of the public before his death. Candid celebrity photography 
was well established in Britain and it was meant to create a visual immediacy and reality in the way it caught the subject off guard. ${ }^{92}$ However, as already discussed in relation to the Sketch's 1922 long-distance photo of Lawrence, the indistinct features it conveyed served only to compound the mystery encircling Aircraftman Ross. This was also the case with the photographs taken of Lawrence as he disembarked from the passenger liner that had carried him back to England after his time in India in 1929. Although these images were reproduced in the pages of the popular press, the long-distance nature of the photographs of the small man in the dark RAF raincoat and hat did little to bring audiences closer to Lawrence. ${ }^{93}$

Lawrence's disembarkation in 1929 was also the first occasion on which the war hero was presented to cinema audiences in British newsreels. ${ }^{94}$ Preceding the arrival of sound in newsreels later in the same year, the Gaumont Graphic presented silent moving images of Lawrence's landing with a subtitle screen that stated how their 'cameraman [had] secure[d] exclusive pictures of "elusive Lawrence". ${ }^{95}$ These images probably served to inspire interest in his motives for avoiding publicity, whilst briefly bringing cinema audiences closer to him. In the first six years of the sound newsreel which brought media audiences into more intimate contact with celebrities than ever before, there was no newsreel coverage of Lawrence. ${ }^{96}$ Not until his death did he reappear on screen and, two weeks after his funeral, British Movietone News released a film which, as its narrator claimed, showed pictures of Lawrence 'in England with an American friend' ${ }^{97} \mathrm{He}$ was stood outside a building, casually dressed, chatting with a smart looking man and woman. The narrator continued that, '[he] posed for the amateur photographer although he shunned the professional camera.' These images, which included close-ups of Lawrence's face, were again meant to bring viewers closer to him. This film also showed images of him sat picnicking with friends. The commentator on the Gaumont British News film, which used the same newsreel footage, commented that these were 'surroundings of the most delightful informality. ${ }^{98}$ Cinemagoers had not been presented with unofficial images of Lawrence like these before. These intimate 'behind-the-scenes' films, which were meant to convey to viewers Lawrence's 'real' self through the revelation of his domestic life, had been denied audiences during his lifetime. Now, in the wake of his death, the newsreels 
enhanced his celebrity persona by presenting images of him that seemed normal and private.

The British Movietone film included in its commentary on the scenes of the war hero amongst his friends that 'we make no excuse for reverting to this subject again a week after our previous film... because so few pictures of Lawrence moving or still are in existence owing to his dislike of publicity during his lifetime.' This statement suggests how Lawrence's remoteness was enhanced by the scarcity of visual images of him in circulation. His indistinct and aloof visuality undermined a popular celebrity culture which placed increasing emphasis on the need for famous people's visual identities to be at once recognisable and, increasingly, candid. ${ }^{99}$ Indeed, given the paucity of photographs of Lawrence that newspapers had at their disposal, many instead used artistic portraits of him to illustrate their reports. ${ }^{100}$ Historians of visual culture have noted how photographed images have a greater affinity with reality than artistic portrayals, the latter offering a more romantic, imaginative likeness of the subject. ${ }^{101}$ When the press reproduced pictures like James McBey's famous painting of Lawrence in Arab dress in 1918 they were thus encouraging readers to assimilate a persona of the war hero that merged the realms of fantasy and reality, simultaneously shrouding an image of a 'real' self behind the robes of the Blonde Bedouin. ${ }^{102}$

\section{Conclusion}

This article has examined T. E. Lawrence's changing media representation in the period 1919 to 1935 to show how a new culture of fame emerged in Britain in which the media sought to expose celebrity's private lives to foster empathy between them and a mass public. Until the late 1920s, newspapers portrayed Lawrence as a mysterious adventurer, based on the dynamic 'Lawrence of Arabia' figure created by Lowell Thomas. This image intersected with a wider culture of conspiracy which surrounded government activities in this period. Yet, Lawrence's duplicitous image as a secret agent came under increasing strain in these years before finally collapsing with the 'arch-spy of the world' story in 1929. Instead, in accordance with broader shifts in the British media's creation of celebrities, reporters switched their focus to the 'real' Lawrence who, they claimed, lay behind the remote public image. To construct an authentic 
vision of the 'real' man, journalists like the Express's James Douglas discussed his domestic circumstances and activities at a time when private life was increasingly viewed as the main locus for true emotional self-actualization. Later reports also focused on Lawrence's private thoughts and feelings in order to try and convey his inner affective state, while visual images used by the media following his death presented a more intimate and personal representation of him than ever before.

In his lifetime, Lawrence had embraced anonymity as an aircraftman to rid himself of press attention, but his deliberate attempts at self-effacement only stimulated the media's interest in him. In these years, popular celebrities presented journalists access to versions of their so-called private lives in order to create images of their 'real' selves with which media audiences could identify but Lawrence's reluctance to court publicity frustrated this process, destabilizing this media-orchestrated culture of fame. By cultivating a reputation that was defined by its remoteness, Lawrence subverted the relationship between celebrities and the public in a period beset by growing anxieties concerning how the famous communicated their social power to audiences through new kinds of media. Contradictorily, this aloofness merely motivated journalists to intensify their investigations into Lawrence in an attempt to rebalance this relationship between the unwilling celebrity and mass public by making a more intimate image of him available to their audiences.

\section{Acknowledgements}

My thanks is due, first, to the AHRC for the research support during my Masters year which allowed me to conduct an examination of T. E. Lawrence's media image for my dissertation; secondly, to Frank Mort, James Greenhalgh, Maarten Walraven, Sarah Wood, Ian Field, James Corke-Webster and seminar audiences in Manchester, Brighton, Sheffield and Lancaster for their comments on drafts and papers; thirdly, to the anonymous referees who made a number of valuable suggestions; and, finally, my special thanks to Max Jones whose constant support and guidance, from the conception of this project to its completion, has been invaluable and greatly appreciated. 
${ }^{1}$ Britain, rather than England, because the newspapers and newsreels examined here were distributed to media audiences across Britain.

${ }^{2}$ The best biography of Lawrence is J. Wilson, Lawrence of Arabia: The Authorised Biography (London, 1989). S. E. Tabachnick \& C. Matheson, Images of Lawrence (London, 1988) offers a useful survey of the changing biographical treatment of Lawrence.

${ }^{3}$ G. Dawson, Soldier Heroes: British Adventure, Empire and the Imagining of Masculinity (London, 1994), pp.167-232. For similar analyses, also see J. M. MacKenzie, 'Heroic Myths of Empire', in J. M. MacKenzie (ed.), Popular Imperialism and the Military, 1850-1950 (Manchester, 1992), pp.109-138; J. C. Hodson, Lawrence of Arabia and American Culture: The Making of a Transatlantic Legend (Westport, 1995).

${ }^{4}$ P. Satia, 'Inter-war Agnotology: Empire, Democracy and the Production of Ignorance', in L. Beers \& G. Thomas (eds.), Brave New World: Imperial and Democratic Nation Building in Britain Between the Wars (London, 2011), p.217. P. Satia, Spies in Arabia: The Great War and the Cultural Foundations of Britain's Covert Empire in the Middle East (Oxford, 2008).

${ }^{5}$ On using newspapers as historical sources and for terminologies see A. Bingham, Gender, Modernity and the Popular Press (Oxford, 2004), pp.12-15. For this investigation, over 700 press reports were sampled from seventeen daily and weekly national newspapers located at the old British newspaper archive in Colindale and online. The elite publications sampled were the Daily Telegraph; Manchester Guardian; The Observer; and The Times. The popular newspapers sampled were the Daily Express; Daily Herald; Daily Mail; Daily Mirror; Daily News; Daily Sketch; Empire News; Illustrated London News; News Chronicle; News of the World; Sunday Express; Sunday Pictorial; and The People. The newsreels examined include British Movietone News, Gaumont Graphic; Gaumont British News.

${ }^{6}$ Satia, 'Inter-war Agnotology', p.217.

${ }^{7}$ Dawson, Soldier Heroes, p.167.

${ }^{8}$ For a useful review article on modern celebrity culture see S. Morgan, 'Celebrity: Academic 'PseudoEvent' or a Useful Concept for Historians?', Cultural and Social History 8:1 (2011), pp.95-114.

${ }^{9}$ G. Turner, Understanding Celebrity (London, 2014), p.8.

${ }^{10}$ On the production of empathy between celebrities and media audiences see R. Schickel, Intimate Strangers: The Culture of Celebrity in America (Chicago, 2000); R. Dyer, Stars (London, 2004). 
${ }^{11}$ C. L. Ponce de Leon, Self-Exposure: Human-Interest Journalism and the Emergence of Celebrity in America, 1890-1940 (London, 2002).

${ }^{12}$ S. Marcus, Between Women: Friendship, Desire, and Marriage in Victorian England (Princeton, 2007), p.37. Also see M. Thompson, Psychological Subjects: Identity, Culture and Health in Twentieth-Century Britain (Oxford, 2006), esp. Chapter 1; N. Rose, Governing the Soul: The Shaping of the Private Self (London, 1999); C. Taylor, Sources of the Self: The Making of Modern Identity (Cambridge, 1989); Ponce de Leon, Self-Exposure, p.5 and pp.29-40.

${ }^{13}$ C. Langhamer, 'Love, Selfhood and Authenticity in Post-War Britain', Cultural and Social History 9:2 (2012), pp.277-297; N. Rose, Inventing Ourselves: Psychology, Power and Personhood (Cambridge, 1996), p.3.

${ }^{14}$ L. Beers, ‘A Model MP? Ellen Wilkinson, Gender, Politics and Celebrity Culture in Interwar Britain', Cultural and Social History 10:2 (2013), pp.232-3.

${ }^{15}$ Ponce de Leon, Self-Exposure, p.5 and pp.29-40.

${ }^{16}$ M. Houlbrook, 'Commodifying the Self Within: Ghosts, Libels, and the Crook Life Story in Interwar Britain', Journal of Modern History 85:2 (2013), p.322.

${ }^{17}$ T. Mole, Byron's Romantic Celebrity: Industrial Culture and the Hermeneutic of Intimacy (Basingstoke, 2007), pp.1-5 and 22-3.

${ }^{18}$ This article does not subscribe to the argument that Lawrence engaged in self-effacement as a publicity strategy but it is clear that he was concerned about maintaining his aloof public image. For the view that Lawrence deliberately courted attention by shying away from the media, see S. Ashley, 'Introduction', in S. Ashely (ed.), Robert Graves: Count Belisarius and Lawrence and the Arabs (Manchester, 2004), p.viii. For contemporary accounts see Tabachnick, Images, p.46. For the alternative view adopted by this article, see Wilson, Lawrence, p.852.

${ }^{19}$ Dawson, Soldier Heroes, pp.167-70 and p.188.

${ }^{20}$ Ibid.

${ }^{21}$ Daily Express, 8 January 1920, p.3.

${ }^{22}$ The Times, 7 November 1919, p.12; The Observer, 4 January 1920, p.12.

${ }^{23}$ Hodson, Lawrence, p.45.

${ }^{24}$ Daily Express, 27 December 1922, p.1.

${ }^{25}$ AIR 2692-0-3 pp.30-31 (National Archives PRO). 
${ }^{26}$ For example, see Daily Mirror, 28 December 1922, p.3; Daily Telegraph, 28 December 1922, p.8;

Daily News, 29 December 1922, p.1; The People, 31 December 1922, p.5.

${ }^{27}$ Daily Sketch, 29 December 1922, p.3.

${ }^{28}$ Ibid.

${ }^{29}$ News of the World, 31 December 1922, p.5.

${ }^{30}$ S. Heathorn, Haig and Kitchener in Twentieth-Century Britain: Remembrance, Representation and Appropriation (Farnham, 2013), pp.65-87.

${ }^{31}$ Ibid, p.87.

${ }^{32}$ Daily Mirror, 28 December 1922, p.3; Daily Telegraph, 28 December 1922, p.8. News of the World, 31 December 1922, p.5.

${ }^{33}$ Daily Mirror, 28 December 1922, p.3.

${ }^{34}$ A. McLaren, 'Smoke and Mirrors: Willy Clarkson and the Role of Disguises in Inter-war England', Journal of Social History 40:3 (2007), p.597; Houlbrook, 'Commodifying', pp.337-9.

${ }^{35}$ Heathorn, Haig, p.93; Satia, Spies, p.68.

${ }^{36}$ Daily Express, 27 December 1922, p.1.

${ }^{37}$ Daily Express, 28 December 1922, p.1.

${ }^{38}$ Daily News, 4 February 1929, p.8.

${ }^{39}$ Evening News, 26 September 1928, p.1.

${ }^{40}$ Empire News, 16 December 1928, p.3.

${ }^{41}$ Satia, 'Inter-war', pp.217-18.

${ }^{42}$ Daily Herald, 5 January 1929, p.1; Daily Sketch, 5 January 1929, p.3; Daily News, 5 January 1929, p.7.

${ }^{43}$ Daily Telegraph, 7 January 1929, p.12; The Observer, 6 January 1929, p.15; The Times, 8 January 1929, p. 12.

${ }^{44}$ Daily News, 4 February 1929, p.9.

${ }^{45}$ Ibid.

${ }^{46}$ Satia, 'Inter-war', pp.217-8.

${ }^{47}$ Daily Express, 7 February 1929, p.3.

${ }^{48}$ Daily News, 4 February 1929, p.9.

${ }^{49}$ Ponce de Leon, Self-Exposure, pp.36-7 and 56-65. 
${ }^{50}$ On the demotic character of American celebrity see L. E. Nym Mayhall, 'The Prince of Wales Versus Clark Gable: Anglophone Celebrity and Citizenship Between the Wars', Cultural and Social History 4:4 (2007), pp.529-543.

${ }^{51}$ D. L. LeMahieu, A Culture for Democracy: Mass Communication and the Cultivated Mind in Britain Between the Wars (Oxford, 1998), pp.107-21.

${ }^{52}$ Daily Mirror, 5 February 1929, p.7.

${ }^{53}$ Daily Express, 30 November 1925, p.8.

${ }^{54}$ Langhamer, 'Love', p. 278.

${ }^{55}$ For example, see L. Riall, Garibaldi: Invention of a Hero (Yale, 2008), pp.252-3 and 311; Ponce de Leon, Self-Exposure, pp.55-7.

${ }^{56}$ Ponce de Leon, Self-Exposure, p.137.

${ }^{57}$ For example, see British Pathé, 'Stars at Home - Miss Nellie Wallace (1921)’ (http://www.youtube.com/watch?v=Q-HXZnI31c8); British Pathé, 'Stars at Home - Matheson Lang (1921)' (https://www.youtube.com/watch?v=3EvKh95tGAk); British Pathé, 'The Stars as They Are Miss Evelyn Laye (1924)’ (https://www.youtube.com/watch?v=KmIfKJEStuY).

${ }^{58}$ Daily News, 29 December 1922, p.1.

${ }^{59}$ Bingham, Gender, pp.166-70; Mayhall, 'The Prince', pp.531-2; Ponce de Leon, Self-Exposure, pp.120-9.

${ }^{60}$ Daily Express, 15 May 1929, p.10. Also see Hodson, Lawrence, pp.68-71; E. Gargano, “'English Sheiks' and Arab Stereotypes: E. M. Hull, T. E. Lawrence, and the Imperial Masquerade', Texas Studies in Literature and Language 48:2 (2006), pp.171-186.

${ }^{61}$ Daily Mirror, 14 December 1933, p.12.

${ }^{62}$ R. Aldington, Lawrence of Arabia: A Biographical Enquiry (New York, 1955); P. Knightley \& C. Simpson, The Secret Lives of Lawrence of Arabia (London, 1969), pp.158-65 and 203-17; J. E. Mack, A Prince of Our Disorder: The Life of T. E. Lawrence (Harvard, 1998: London, 1976); Tabachnick, Images, pp.21 and 51-5.

${ }^{63}$ Mack, A Prince, pp.415-441, esp. p.427 and footnote 36 on p.523.

${ }^{64}$ Ibid, p.425.

${ }^{65}$ Daily Mirror, 11 March 1927, p.7. 
${ }^{66}$ M. Jones, 'National Hero and Very Queer Fish': Empire, Sexuality and the British Remembrance of General Gordon, 1918-72', Twentieth-Century British History (advance access - 2014), p.10.

${ }^{67}$ Notably, on the day of Lawrence's funeral the Mirror (21 May 1935, p.5) began to speculate that his dedication in Seven Pillars was in fact a poem to a secret lover, and Knightley and Simpson later made the claim that it was written about a young Arab man named Dahoum (Secrets, pp.158-65). Equally, after Lawrence's death, E. M. Forster broadcasted a review of the public edition of Seven Pillars and included in his description that it contained 'a sexual frankness which would cause most authors to be run in by the police' (published in The Listener, 31 July 1935).

${ }^{68}$ L. Braudy, The Frenzy of Renown: Fame and its History (Oxford, 1986), pp.375-6.

${ }^{69}$ Daily Express, 23 December 1927, p.6.

${ }^{70}$ Daily Express, 31 May 1928, p.8.

${ }^{71}$ D. Boorstin, The Image: A Guide to Pseudo-Events in America (New York, 1962), p.69.

${ }^{72}$ Daily Express, 7 February 1929, p.10.

${ }^{73}$ Daily Express, 7 August 1929, p.8.

${ }^{74}$ B. Rieger, Technology and the Culture of Modernity in Britain and Germany, 1890-1945

(Cambridge, 2005), p.149.

${ }^{75}$ Mayhall, 'The Prince of Wales'.

${ }^{76}$ E. Owens, “"All the World Loves a Lover”: Royal Romance and the Enchantment of Constitutional Monarchy in Interwar Britain', Social History Society 2013.

http://www.gellius.net/downloads/org_3/owensshs25march.pdf

${ }^{77}$ Daily Mirror, 14 December 1933, p.12.

${ }^{78}$ Ponce de Leon, Self-Exposure, p.89.

${ }^{79}$ F. Inglis, A Short History of Celebrity (Oxford, 2010), pp.186-159; H. Bergmeier \& R. Lotz, Hitler's Airwaves: The Inside Story of Nazi Radio Broadcasting and Propaganda Swing (Yale, 1997).

${ }^{80}$ D. Giles, Illusions of Immortality: A Psychology of Fame and Celebrity (Basingstoke, 2000), pp.71-4.

${ }^{81}$ News Chronicle, 11 May 1934, p.1.

${ }^{82}$ For example, see Daily Express, 16 January 1925, p.1; Daily Mirror, 29 February 1936, p.1.

${ }^{83}$ Houlbrook, 'Commodifying', pp.332-5.

${ }^{84}$ AIR 2692-0-2 pp.10-15 (57). 
${ }^{85}$ For example, see Daily Sketch, 15 May 1935, p.2; Daily Mail, 15 May 1935, p.13; Daily Herald, 22 May 1935, p.7.

${ }^{86}$ Daily Mirror, 14 May 1935, p.1.

${ }^{87}$ Daily Herald, 16 May 1935, p.1; News Chronicle, 20 May 1935, p.1.

${ }^{88}$ For example, see Daily Mail, 4 September 1922, p.9; Daily News, 4 February 1929, p.9; Daily

Express, 27 February 1931, p.11.

${ }^{89}$ For example, see Daily Sketch, 20 May 1935, p.1; Daily Mirror, 20 May 1935, p.9.

${ }^{90}$ Daily Express, 28 May 1920, p.1; Daily Express, 28 December 1922, p.1.

${ }^{91}$ Illustrated London News, 25 May 1935, p.947. Tabachnick suggests this series of photographs was taken in late 1931 (Images, p.75). Coster's photographs would also appear in the first posthumous biography of Lawrence, V. Richards, Portrait of T. E. Lawrence (London, 1936).

${ }^{92}$ R. Linkof, “"The Photographic Attack on His Royal Highness”: The Prince of Wales, Wallis Simpson and the Prehistory of the Paparazzi', Photography and Culture 4:3 (2011), pp.277-292.

${ }^{93}$ Sunday Pictorial, 3 February 1929, p.1

${ }^{94}$ For a brief history of newsreels, see

http://bufvc.ac.uk/wp-content/media/2009/06/newsreels_long_history.pdf

${ }^{95}$ Gaumont Graphic, 8 February 1929, 'Aircraftman Shaw'.

${ }^{96}$ See Owens, 'All the World'.

${ }^{97}$ British Movietone News, 3 June 1935, 'New Film of Lawrence of Arabia'.

http://www.aparchive.com/search?startd $=$ \&endd $=\&$ allFilters $=$ British + Movietone\%7C43894\%3APart ner $\&$ query $=n e w+$ film + of + lawrence + of + arabia $\&$ advsearchStartDateFilter $=\& a d v$ searchEndDateFilt er $=\&$ searchFilterHdSDFormat $=$ All \&searchFilterDigitized $=$ All \&searchFiltercolorFormat $=$ All \&searc hFilteraspectratioFormat $=$ All\&searchPartner $=$ British + Movietone $\% 7 C 43894$

${ }^{98}$ Gaumont British News, 3 June 1935, 'The Late Colonel Lawrence in America'.

${ }^{99}$ Ponce de Leon, Self-Exposure, pp.63-5.

${ }^{100}$ For example, see Daily Express, 27 December 1922, p.1; Sunday Express, 30 September 1928, p.1; Sunday Express, 19 May 1935, p.1.

${ }^{101}$ P. Burke, Eyewitnessing: The Uses of Images as Historical Evidence (London, 2001), pp.21-2.

${ }^{102}$ Dawson, Soldier Heroes, p.167. 